\title{
Hubungan Jumlah Komplikasi Kronik Dengan Derajat Gejala Depresi Pada Pasien Diabetes Melitus Tipe 2 Di Poliklinik Rsup Dr. M. Djamil Padang
}

\author{
Try Rahmi Lussii Karsuita ${ }^{1}$, Eva Decroli ${ }^{2}$, Delmi Sulastri ${ }^{3}$
}

\begin{abstract}
Abstrak
Komplikasi akibat penyakit Diabetes Melitus (DM) dapat menyebabkan terjadinya perubahan psikologis, salah satunya adalah gejala depresi pada pasien DM. Tujuan penelitian ini adalah menentukan perbedaan jumlah komplikasi kronik pada setiap derajat depresi pada pasien DM tipe 2. Penelitian ini menggunakan desain analitik observasional yang dilaksanakan dari Maret sampai Mei 2014 di Poliklinik RSUP Dr. M. Djamil Padang. Sampel dalam penelitian ini terdiri dari 76 pasien DM. Jumlah komplikasi kronik diketahui dengan melihat rekam medik pasien, sedangkan derajat gejala depresi dinilai dengan wawancara menggunakan kuesioner Beck Depression Inventory (BDI) II. Hasil penelitian menunjukkan bahwa responden yang mengalami gejala depresi sebanyak 27 orang (35,5\%). Derajat gejala depresi normal atau minimal sebanyak $64,5 \%$, derajat ringan sebanyak $27,6 \%$ dan derajat sedang sebanyak 7,9\%. Gejala depresi pada responden dengan satu komplikasi sebesar 6,9\%, dengan dua komplikasi $42,4 \%$, dengan tiga komplikasi $88,8 \%$ dan empat komplikasi sebesar $60 \%$. Setelah dilakukan analisis dengan uji Kruskal Wallis didapatkan bahwa terdapat perbedaan rerata jumlah komplikasi kronik pada setiap derajat depresi pada pasien DM tipe 2 ( $p<0,001)$.
\end{abstract}

Kata kunci: diabetes melitus tipe 2, gejala depresi, komplikasi kronik

\begin{abstract}
Complications due to diabetes disease can cause psychological changes, such as depression symptom. The objective of this study was to reveal the difference of the number of chronic complications on every single degree of depression in patients with type 2 diabetes. This was an analytic study that carried out from March to May 2014 in the polyclinic of RSUP Dr. M. Djamil Padang. The subject consisted of 76 diabetic patients. The number of chronic complications was identified by looking at the medical record of patients, whereas the degree of depressive symptom assessed by interview using a questionnaire BDI II. The results showed that respondents having depression symptom are made up by 27 people (35.5\%). The amount of normal or minimal depression was $64.5 \%$, mild depression is 27.6 $\%$, and $7.9 \%$ for moderate depression. Depression symptoms on the respondents that having one complication is $6.9 \%, 42.4 \%$ for two complications, $88 \%$ for three complications and $60 \%$ for four complications. Kruskal Wallis test showed that there is the difference of the mean of chronic complication on every single degree of depression.
\end{abstract}

Keywords: :type 2 diabetes mellitus, depression symptoms, chronic complications

Affiliasi penulis: Prodi Profesi Dokter FK UNAND (Fakultas Kedokteran Universitas Andalas Padang, 2. Bagian Penyakit Dalam FK UNAND/RSUP dr. M.Djamil Padang, 3. Bagian IImu Gizi FK UNAND

Korespondensi: Try Rahmi Lussii, Email : lussiikarsuita@gmail.com Telp: 085274131861

\begin{abstract}
PENDAHULUAN
Diabetes melitus (DM) merupakan suatu sindrom kronik gangguan metabolisme karbohidrat, protein, dan lemak akibat ketidak cukupan sekresi insulin atau terjadinya resistensi insulin pada jaringan. ${ }^{1}$
\end{abstract}


Berbagai penelitian epidemiologi menunjukkan kecenderungan peningkatan insiden dan prevalensi diabetes di berbagai belahan dunia. Sebanyak 347 juta orang di seluruh dunia menderita diabetes. Pada tahun 2004, sebanyak 3,4 juta orang diperkirakan meninggal karena konsekuensi gula darah tinggi. ${ }^{2}$

Kontrol DM yang buruk dapat mengakibatkan hiperglikemia dalam jangka panjang, yang menjadi pemicu beberapa komplikasi yang serius.Manifestasi komplikasi kronik dapat terjadi pada tingkat pembuluh darah kecil (mikrovaskuler) dan pembuluh darah besar (makrovaskuler). Pada tingkat mikrovaskuler, maka manifestasi komplikasi kronik DM dapat terjadi pada retina mata (retinopati diabetik) dan glomerulus ginjal (nefropati diabetik). Pada pembuluh darah besar (makrovaskular) dapat ditemukan komplikasi pada otak (stroke), jantung (penyakit jantung koroner) dan pembuluh darah kaki. Komplikasi lain DM dapat berupa neuropati dan kerentanan berlebih terhadap infeksi dengan akibat mudahnya terjadi infeksi kaki, kemudian dapat berkembang menjadi ulkus/gangren diabetes. $^{3}$

Banyaknya komplikasi yang mengiringi penyakit DM telah memberikan kontribusi terjadinya perubahan fisik maupun psikologis. Salah satu perubahan psikologis yang paling sering terjadi adalah gejala depresi pada pasien DM. Penelitian sebelumnya telah meneliti hubungan antara depresi dengan komplikasi mikro dan makrovaskuler diabetes dan ada bukti yang menunjukkan bahwa komplikasi jangka panjang dari diabetes berhubungan dengan gejala depresi. ${ }^{4}$

Beban psikososial akibat manajemen diabetes dan kejadian komplikasi dapat menyebabkan gangguan fungsional dan mempengaruhi keparahan depresi pada pasien.Respon psikologis akibat komplikasi diabetes dapat menyebabkan episode depresi yang berkepanjangan atau berulang. Beban akibat perawatan diabetes, yang meliputi pengelolaan komplikasi, pantangan dan pemantauan kadar glukosa secara signifikan dapat mengurangi kualitas hidup dan berkontribusi untuk terjadinya gangguan afektif. ${ }^{5}$

Tingginya prevalensi depresi pada penderita diabetes cukup memprihatinkan karena depresi dapat menghambat manajemen diabetes. Ketika depresi menyertai diabetes, ada bukti penurunan kontrol kadar glikemik, penurunan aktivitas fisik, peningkatan obesitas dan berpotensi mengalami komplikasi dan gangguan fungsi. Ada juga bukti bahwa depresi pada penderita diabetes berhubungan dengan penurunan kepatuhan dalam pengobatan dengan obat hipoglikemik oral. ${ }^{6}$ Adanya gejala depresi mempunyai implikasi negatif pada manajemen diabetes dengan komplikasi.

\section{METODE}

Penelitian ini merupakan penelitian analitik dengan pendekatan cross sectional study yang bertujuan untuk menentukan perbedaan jumlah komplikasi kronik pada setiap derajat gejala depresi pada pasien DM tipe 2. Sampel penelitian sebanyak 76 orang pasien DM tipe 2 yang melakukan pemeriksaan di poliklinik penyakit dalam RSUP Dr.M.Djamil Padang. Kriteria inklusi adalah pasien DM tipe 2 dengan komplikasi kronik dan bersedia menjadi responden. Kriteria eksklusi adalah pasien yang mengalami penurunan kesadaran dan gangguan kognitif.

Variabel dependen adalah jumlah komplikasi kronik, sedangkan variabel independen adalah derajat gejala depresi. Penelitian ini dilakukan di Poliklinik Khusus RSUP Dr. M. Djamil Padang selama tiga bulan, yakni dari Maret sampai Mei 2014. Langkahlangkah pengolahan data adalah setelah data terkumpul, data diedit lalu dilakukan pengkodean kemudian dilakukan tabulasi. Analisis data statistik dengan menggunakan dua cara yaitu univariat dan bivariat. Analisis univariat digunakan untuk mengetahui jumlah komplikasi kronik dan derajat gejala depresi pada penderita DM tipe 2. Analisis bivariat digunakan untuk melihat perbedaan jumlah komplikasi kronik pada setiap derajat gejala depresi dengan menggunakan uji one way ANOVA yang merupakan uji parametrik, namun jika data yang diperoleh tidak memenuhi persyaratan uji parametrik maka akan digunakan uji Kruskal-Wallis. 
HASIL

\section{Karakteristik Pasien DMTipe 2 dengan Komplikasi} Kronik

Tabel 1. Distribusi pasien DM tipe 2 dengan komplikasi kronik berdasarkan jenis kelamin dan usia

\begin{tabular}{|c|c|c|c|}
\hline \multicolumn{2}{|c|}{ Karakteristik } & $f$ & (\%) \\
\hline \multicolumn{4}{|c|}{ Jenis Kelamin } \\
\hline - & Laki-laki & 35 & 46,1 \\
\hline - & Perempuan & 41 & 53,9 \\
\hline \multicolumn{4}{|c|}{ Usia (tahun) } \\
\hline - & $<50$ & 4 & 5,3 \\
\hline - & $50-59$ & 41 & 54 \\
\hline - & $60-69$ & 26 & 34,2 \\
\hline - & $\geq 70$ & 5 & 6,5 \\
\hline
\end{tabular}

Sebagian besar pasien Diabetes Melitus tipe 2 dengan komplikasi kronik dalam penelitian ini berjenis kelamin perempuan, yakni sebanyak 53,9\%. Pasien yang termuda adalah 37 tahun dan yang paling tua adalah 80 tahun. Usia rata-rata pasien adalah 58,82 tahun (SD 7,52) dan yang terbanyak terdapat pada kelompok usia 50 sampai 59 tahun (54\%).

Distribusi Jumlah Komplikasi Kronik dan Derajat Gejala Depresi pada Pasien DM tipe 2 dengan Komplikasi Kronik

Tabel 2. Distribusi jumlah komplikasi kronik

\begin{tabular}{ccc}
\hline $\begin{array}{c}\text { Jumlah Komplikasi } \\
\text { Kronik }\end{array}$ & $\mathbf{f}$ & $\%$ \\
\hline 1 & 29 & 38,2 \\
2 & 33 & 43,4 \\
3 & 9 & 11,8 \\
4 & 5 & 6,6 \\
\hline Total & 76 & 100 \\
\hline
\end{tabular}

Tabel 3. Distribusi derajat gejala depresi

\begin{tabular}{ccc}
\hline Derajat depresi & $\mathbf{f}$ & $\%$ \\
\hline Normal atau minimal & 31 & 68,9 \\
Ringan & 10 & 22,2 \\
Sedang & 4 & 8,9 \\
\hline Total & 45 & 100 \\
\hline
\end{tabular}

Hasil penelitian dengan teknik wawancara pasien dan dipastikan dengan data rekam medis, didapatkan pasien terbanyak memiliki dua jenis komplikasi (43,4\%). Berdasarkan hasil penelitian mengenai derajat gejala depresi dengan kuesioner BDI didapatkan skor terendah 1 dan skor tertinggi 25 dengan rata-rata skor adalah 9. Berdasarkan skor yang diperoleh, pasien DM tipe 2 dengan komplikasi kronik yang tidak mengalami gejala depresi sebanyak $64,5 \%$, sedangkan pasien dengan gejala depresi (skor $\geq 10$ ) sebanyak $35,5 \%$. Pasien dengan gejala depresi ringan sebanyak 27,6\%, gejala depresi sedang sebanyak $7,9 \%$, dan tidak didapatkan pasien dengan gejala depresi berat.

\section{Hubungan Jumlah Komplikasi Kronik dengan Derajat Gejala Depresi pada Pasien DM tipe 2}

Tabel 4. Hubungan jumlah komplikasi kronik dengan derajat gejala depresi pada pasien DM tipe 2

\begin{tabular}{cccc}
\hline $\begin{array}{c}\text { Derajat gejala } \\
\text { depresi }\end{array}$ & $\mathbf{f}$ & $\begin{array}{c}\text { Median } \\
\text { (minimum- } \\
\text { maksimum) }\end{array}$ & p \\
\hline Normal & 49 & $1(1-4)$ & \\
Ringan & 21 & $2(1-4)$ & $<0,001$ \\
Sedang & 6 & $3(2-4)$ & \\
\hline
\end{tabular}

Berdasarkan hasil analisis dengan menggunakan uji Kruskal Wallis didapatkan $p=0,001$ (dimana nilai $\mathrm{p}$ yang dianggap bermakna adalah $<0,05)$, yang artinya paling tidak terdapat perbedaan jumlah komplikasi yang bermakna pada dua kelompok derajat gejala depresi.

\section{PEMBAHASAN}

\section{Karakteristik Pasien Diabetes Melitus tipe 2 dengan Komplikasi Kronik}

Sebagian besar pasien diabetes melitus tipe 2 dengan komplikasi kronik dalam penelitian ini berjenis kelamin perempuan, yakni sebanyak 53,9\%, sedangkan pasien laki-laki sebanyak 46,1\%. Jumlah komplikasi yang paling banyak ditemukan pada pasien DM tipe 2 adalah sebanyak 2 jenis komplikasi, yaitu sebesar 43,4\%, sedangkan yang paling jarang ditemukan adalah pasien dengan 4 komplikasi, yaitu sebesar 6,6\%. Sebagian besar pasien laki-laki memiliki 2 komplikasi (48,6\%) sedangkan sebagian besar pasien perempuan memiliki satu komplikasi (41,5\%).Pasien DM tipe 2 dengan komplikasi kronik yang paling banyak mengalami gejala depresi ringan dan sedang adalah pasien perempuan yaitu sebanyak $41,5 \%$, sedangkan laki-laki sebanyak $28,6 \%$. Hasil 
penelitian ini tidak jauh berbeda dengan penelitian yang dilakukan oleh Anderson et al pada tahun 2001 yang mendapatkan prevalensi depresi secara signifikan lebih tinggi pada wanita diabetes (28\%) dibandingkan pada pria diabetes $(18 \%){ }^{7}$

Banyak penelitian menyebutkan bahwa perempuan memiliki resiko depresi dua kali lebih tinggi dibandingkan laki-laki. Hal tersebut sebagaimana dikemukakan Hawari (2001) bahwa perempuan beresiko dua kali lebih besar untuk mengalami depresi di banding laki-laki. Perempuan lebih banyak menggunakan perasaan dan emosi dalam menyelesaikan masalah. ${ }^{8}$ Penelitian sebelumnya menyatakan bahwa depresi lebih sering terjadi pada perempuan karena perempuan lebih sering terpajan dengan stressor lingkungan dan ambangnya terhadap stressor lebih rendah bila dibandingkan dengan lakilaki. $^{9}$

Berdasarkan umur, responden yang paling banyak mengalami gejala depresi ringan dan sedang berusia rata-rata 57 dan 53 tahun, sedangkan responden yang tidak mengalami gejala depresi berusia rata-rata 60 tahun. Hasil ini sesuai dengan penelitian Poongothai et al tahun 2011 yang mendapatkan bahwa usia rata-rata responden yang mengalami gejala depresi lebih muda dibanding responden yang tidak mengalami gejala depresi. ${ }^{10}$ Hasil penelitian ini berbeda dengan yang dilakukan oleh Campayo (2010) dimana usia rata-rata responden yang mengalmi gejala depresi (74 tahun) lebih tua dibanding responden yang tidak mengalami gejala depresi (72 tahun). ${ }^{11}$

\section{Hubungan Jumlah Komplikasi Kronik dengan Derajat Gejala Depresi pada Pasien Diabetes Melitus tipe 2}

Berdasarkan hasil penelitian mengenai derajat gejala depresi dengan kuesioner BDI didapatkan skor terendah 1 dan skor tertinggi 25 dengan rata-rata skor adalah 9. Berdasarkan skor yang diperoleh, pasien DM tipe 2 dengan komplikasi kronik yang tidak mengalami gejala depresi sebanyak 64,5\%, sedangkan pasien dengan gejala depresi (skor $\geq 10$ ) sebanyak $35,5 \%$. Pasien dengan gejala depresi ringan sebanyak $27,6 \%$, gejala depresi sedang sebanyak
7,9\%, dan tidak didapatkan pasien dengan gejala depresi berat.

Hasil penelitian ini tidak jauh berbeda dengan yang dilakukan oleh Anderson et al (2001) yang mendapatkan prevalensi depresi pada penderita diabetes melitus tipe 2 sebesar 32,9\%. ${ }^{7}$ Penelitian Katon et al tahun 2004 disebutkan sebanyak 31\% penderita diabetes melitus mengalami gejala depresi. Penderita diabetes berisiko tinggi mengalami depresi untuk jenis kelamin perempuan, usia yang lebih muda, pendidikan kurang dan pendapatankurang. ${ }^{5}$

Penelitian Poongothai et al tahun 2011 didapatkan prevalensi depresi lebih tinggi pada penderita DM dengan retinopati (35\%) dibandingkan dengan tanpa retinopati $(21,1 \%)$. Prevalensi depresi juga lebih tinggi pada penderita DM dengan neuropati $(28,4 \%)$ dibandingakan tanpa neuropati $(21,1 \%)$ dan juga lebih tinggi pada penderita DM dengan nefropati $(35,6 \%)$ dibandingkan tanpa nefropati $(22,7 \%) .{ }^{10}$ Pada penelitian Raval et al tahun 2010 juga didapatkan prevalensi depresi yang lebih tinggi pada penderita DM dengan komplikasi, terutama neuropati, nefropati, dan kaki diabetik. ${ }^{12}$

Hasil uji Kruskal Wallis didapatkan perbedaan rata-rata jumlah komplikasi yang signifikan secara statistik antara derajat gejala depresi normal dibandingkan dengan derajat gejala depresi ringan ( $p=0,000)$, antara derajat gejala depresi normal dengan derajat gejala depresi sedang $(p=0,000)$, dan antara derajat gejala depresi ringan dengan derajat gejala depresi sedang $(p=0,112)$. Jumlah komplikasi rata-rata paling sedikit terdapat pada derajat gejala depresi normal atau minimal yaitu sebanyak 1,55 . Jumlah komplikasi rata-rata terbanyak terdapat pada derajat gejala depresi sedang yaitu 3 .

Sedikit berbeda dengan penelitian yang dilakukan oleh Katon et al pada tahun 2004 yang menyatakan jumlah komplikasi berhubungan signifikan secara statistik dengan depresi pada pria tetapi tidak untuk wanita. Pasien laki-laki dengan depresi hampir dua kali lipat memiliki tiga atau lebih komplikasi $(33,6 \%)$ dibandingkan dengan laki-laki tanpa depresi $(17,4 \%)$. Perempuan dengan depresi yang memiliki tiga atau lebih komplikasi sebesar $17,7 \%$ dan $15,1 \%$ pada mereka yang tidak depresi. ${ }^{5}$ 
Lin et al pada tahun 2010 menyatakan bahwa depresi dan DM tipe 2 dengan komplikasi saling berhubungan. Depresi dapat mengaktifkan aksis Hypothalamic Pituitary Adrenal, merangsang sistem saraf simpatik, meningkatkan respon agregasi platelet dan inflamasi, serta berkontribusi terhadap kontrol glikemik yang buruk sehingga meningkatkan risiko komplikasi diabetes. Depresi juga dapat mengganggu kontrol glikemik melalui efek negatif pada perilaku seperti kepatuhan terhadap diet, olahraga, memeriksa gula darah dan mengambil obat yang diresepkan. Pasien diabetes melitus tipe 2 juga berisiko tinggi mengalami gejala depresi, contohnya pasien dengan komplikasi diabetes seperti nefropati membutuhkan hemodialisis, atau pasien dengan retinopati mengalami gangguan penglihatan yang dapat berakhir menjadi buta, menyebabkan perubahan yang signifikan dalam kehidupan sehari-hari mereka. Stressor yang dihadapi setiap hari dapat menjadi luar biasa yang pada gilirannya dapat memicu terjadinya depresi. ${ }^{6}$

\section{KESIMPULAN}

Terdapat perbedaan rata-rata jumlah komplikasi yang signifikan secara statistik antara derajat gejala depresi normal atau minimal dibandingkan dengan derajat gejala depresi ringan, antara derajat gejala depresi normal atau minimal dengan derajat gejala depresi sedang, dan antara derajat gejala depresi ringan dengan derajat gejala depresi sedang.

\section{DAFTAR PUSTAKA}

1. Dorland N. Kamus kedokteran Dorland. Edisi ke29. Jakarta: EGC; 2002.

2. Anonim. Laporan khusus: upaya menekan dan memantau DM. Ethical DigestcNo.107, Thn.X, Januari 2013. hlm.63.

3. Waspadji S. Kaki diabetes. Dalam: Aru W, et al, editor (penyunting). IImu penyakit dalam Jilid III.
Edisi ke-4. Jakarta: Pusat Penerbitan Departemen IImu Penyakit Dalam FKUI; 2006.

4. de Groot $M$, Anderson R, Freedland KE, Clouse RE, Lustman PJ. Association of depression and diabetes complications: a meta-analysis. Psychosom Med. 2001;63:619-30.

5. Katon WJ, Von Korff M, Ciechanowski P, Russo J, Lin EHB, Simon GE, et al. Behavioral and clinical factors associated with depression among individuals with diabetes. Diabetes Care. 2004; 27:914-20.

6. Lin EHB, Wayne K, Von Korff M, Rutter C, Simon GE, Oliver $M$, et al. Relationship of depression and diabetes self-care, medication adherence, and preventive care. Diabetes Care. 2004;27:2154-60.

7. Anderson RJ, Freedland KE, Clouse RE, Lustman PJ. The prevalence of comorbid depression in adults with diabetes:a meta-analysis. Diabetes Care. 2001;24:1069-78.

8. Hawari D. Manajemen stress, cemas dan depresi. Jakarta : Balai Penerbit FKUI; 2001.

9. Amir N. Depresi aspek neurobiologi diagnosis dan tatalaksana. Jakarta: Balai Penerbit Fakultas Kedokteran Universitas Indonesia; 2005.

10. Poongothai S, Anjana RM, Pradeepa R, Ganesan A, Unnikrishnan $R$, Rema $M$, et al. Association of depression with complications of type 2 diabetes the Chennai Urban rural epidemiology study. JAPI. $2011 ; 59: 640-44$.

11. Campayo A,de Jonge P, Roy JF, Saz P, de la Cámara C, Quintanilla MA, et al. Depressive disorder and incident diabetes mellitus: the effect of characteristics of depression. Am J Psychiatr. 2010;167:580-8.

12. Raval A, Dhanaraj E, Bhansali A, Grover S, Tiwari $P$. Prevalence and determinants of depression in type 2 diabetes patients in a tertiary care centre. Indian J Med Res. 2010;132:195-200. 